\title{
Iconografía fundacional en la historia del Perú*
}

Leopoldo Lituma Aguiero Investigador Independiente leopoldolituma@hotmail.com

\begin{abstract}
Resumen
Luego de la Independencia, la construcción iconográfica devino en indispensable por la necesidad de educar en la historia patria desde un punto de vista vernáculo. Sin embargo fueron extranjeros los primeros que se abocaron a la investigación y compendio de la historia patria desde sus orígenes. Aquellos textos, sin imágenes aún, se utilizaron en la incipiente educación peruana del siglo XIX. A principios del siglo XX aparecieron en el Perú los primeros textos escolares ilustrados, los cuales incorporaron imágenes tomadas de publicaciones foráneas, algunas de ellas con una visión europeizante de lo acontecido en estas tierras. Otras publicaciones menos idealizadas contribuyeron, con sus dibujos y grabados, a la historia visual del país, y cuando fueron incorporados a los libros para educación básica coadyuvaron a crear el imaginario colectivo.

El presente artículo muestra algunas fuentes iconográficas que sirvieron para instruir a la población escolar de principios del siglo XX, varias tomadas como válido referente en diversas situaciones de la historia del Perú, preguntándose cómo pueden haber influido en la conciencia nacional.
\end{abstract}

Palabras clave: Iconografía, Imaginario, Historia, Educación Básica, Perú

\begin{abstract}
After Independence, the building became iconographic indispensable due to the need for education in the country's history from a vernacular perspective. But foreigners were the first to set about the research and compilation of national history from its origins. Those texts, no pictures yet, were used in the emerging nineteenth century Peruvian education.

In the early twentieth century came the first illustrated textbooks, witch incorporated images taken from foreign publications, some with a view of what happened European vision in these lands. Other publications less idealized helped with his drawings and print to the visual history of the country, and when they were incorporated into the books for basic education, helped create a collective imagination. This article shows some iconographic sources that served to educate the school population in the early twentieth century, several taken as a valid reference in various situations in the history of Peru, wondering how it may have influenced national consciousness.
\end{abstract}

Keywords: Iconography, Imagination, History, Basic Education, Perú

\section{Introducción}

El arte contribuye con sus representaciones a la conciencia histórica y a la idea de nación de un país. Aunque la búsqueda de la identidad nacional es un proceso de largo trayecto en el cual historiadores, intelectuales, arquitectos y diversos artífices culturales, van acrecentando el imaginario durante sucesivas generaciones; es cuando un país recién se gesta que la participación e influencia de los artistas es más resaltante dada la necesidad de producción de nueva iconografía que recuerde y perennice los hitos trascendentes en la construcción de la nueva nación.

* El presente artículo es un breve resumen del ensayo del mismo nombre realizado por el autor y premiado como uno de los ganadores de la Bienal de Ensayo COPE 2014. 
Los tiempos posteriores a nuestra independencia son un claro ejemplo de ello; a pocos años de la emancipación, el pintor mulato José Gil de Castro pintó los célebres retratos de Simón Bolívar ${ }^{1}$, y más tarde hizo lo propio con el primer héroe nacional de aquella gesta libertaria: José Olaya. Ambas imágenes perduran hasta hoy y recuerdan en nuestro tiempo la idea de una nación en gestación.

En los siguientes años nuevas pinturas fueron incrementando el arte peruano $\mathrm{y}$, cuando las posibilidades técnicas lo permitieron, dichas imágenes se reprodujeron en los incipientes textos escolares a principios del siglo XX. Al hacerse masivas se incorporaron entonces en la memoria colectiva del peruano, trasmitiendo significados primarios y creando símbolos icónicos.

De las fuentes iconográficas que tuvieron importante repercusión en el Perú consideramos a tres de ellas que nutrieron de imágenes a los autores de textos a principios del siglo XX. Se trata de Les Incas ou la destruction de I'empire du Pèrou de Jean Francois Marmontel publicado en París en 1777 , y su primera edición castellana de 1822; Historia de la Conquista del Perú, de William Prescott, versión en castellano de 1851 adornada con 50 grabados; y América, publicación en tres tomos dotados de numerosos dibujos y grabados, de Rodolfo Cronau, editada en 1892 en conmemoración del IV centenario del descubrimiento de este continente por Cristóbal Colón.
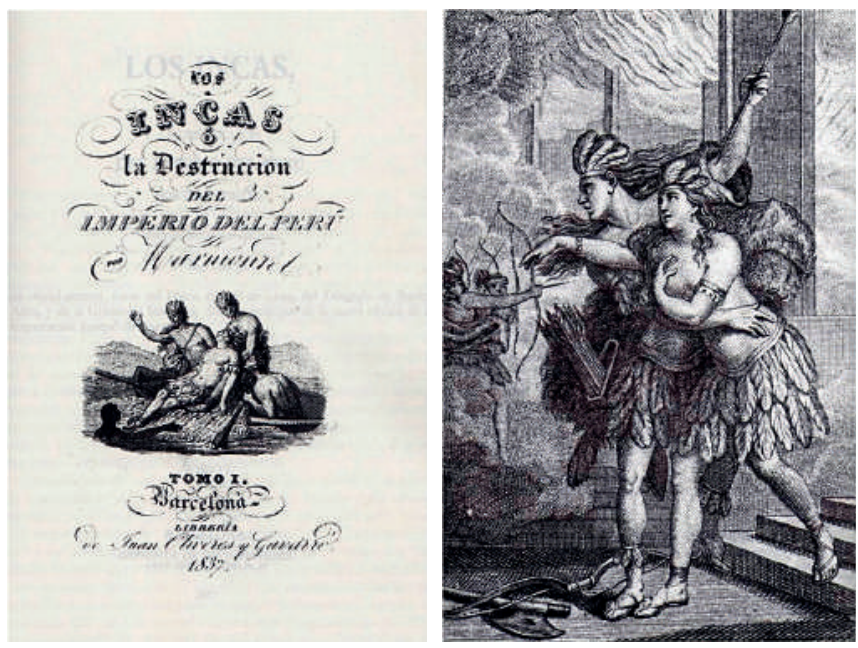

Fig.1 y 2. Carátula del libro Los Incas o la destrucción del Imperio del Perú, y una de las imágenes incorporadas: La Huida del Incendio. El texto que acompaña a la ilustración dice: Arrete! Commence par moi: je me défie de ma main, et je veux mourir de la tienne. (Basta ya! y empieza conmigo pues desconfío de mi mano y deseo morir por la tuya).
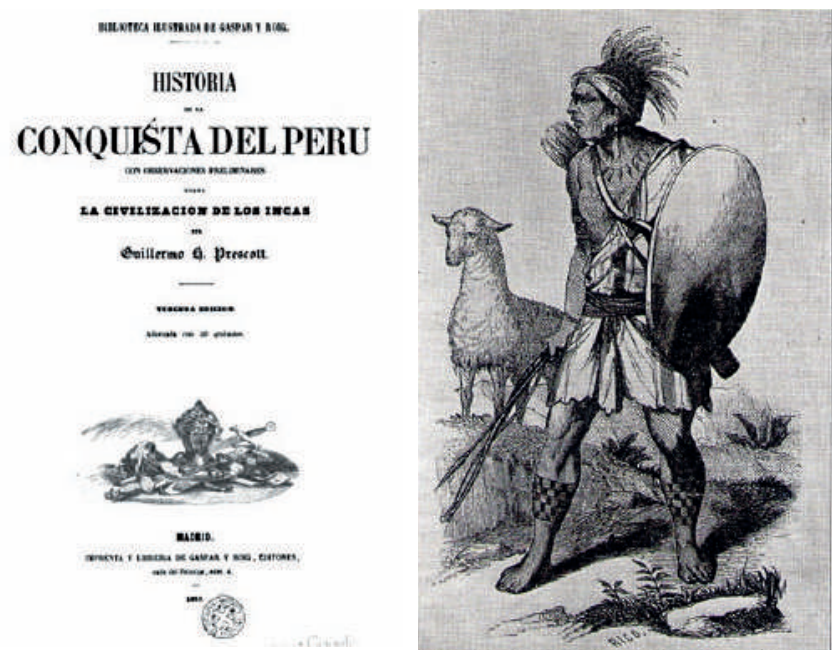

Fig.3 y 4. Carátula del libro de William Prescott (castellanizado a "Guillermo Prescott") editado en Madrid en 1853. Nótese que se trata de la 3ra edición y que en su primera hoja se indica "Adornada con 50 grabados"; y la supuesta imagen de un "Soldado peruano" acompañado de "El llama, rumiante del género de los camélidos".

1 En realidad serían tres retratos los que realizó Gil de Castro, dos de ellos se encuentran en Perú y el tercero en Venezuela. 


\section{Los Incas o la destrucción del Imperio del Perú}

El libro de Jean Francois Marmontel, publicado en París en 1777, tuvo sucesivas ediciones tanto en inglés como en castellano, demostrando la gran acogida y difusión que tuvo. Esta obra fue "una especie de novela poética cuyo fundamento es la historia y la moral su fin", según Jean Francoise de La Harpe, dramaturgo y crítico francés del siglo XVIII.

Les Incas incorpora doce imágenes, todas ellas románticas escenas que recrean a nuestros antepasados prehispánicos dotándolos de valores y nobleza. Éstas reflejan de un lado, la visión de Francia del siglo XVIII acerca del Perú antiguo, y además el poco conocimiento de nuestra cultura en la confluencia con la de los españoles, mostrando a los Incas con arcos y flechas, dentro de escenarios neoclasicistas dotados de mobiliario y utensilios europeos

Los personajes son de tez blanca, de proporciones clásicas, semidesnudos y ataviados con plumas cual indígenas

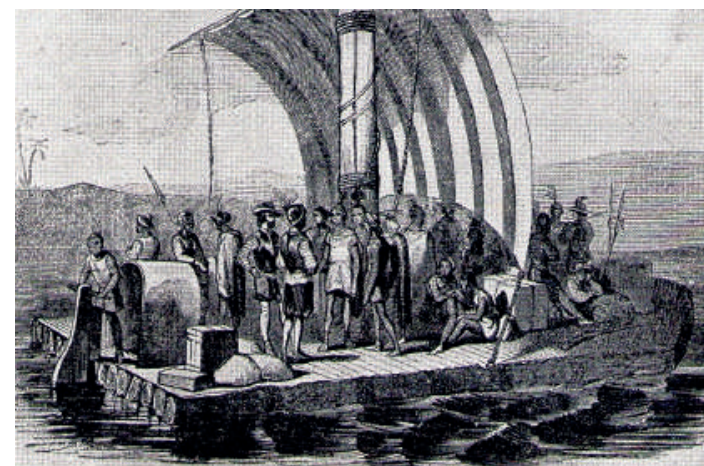

Fig.5. Idealizada balsa a vela, con timonel incluido, donde españoles e incas dialogan y transportan mercancías. Según el autor, estas escenas ocurrirían en una isla de Puná, frente a Guayaquil en Ecuador. de la América central o del norte, seguramente más cercanos al historiador francés. En todas las escenas los supuestos incas aparecen con un semblante digno denotando en ocasiones una postura ejemplificadora y en otras, la desazón por las atrocidades cometidas por sus sojuzgadores españoles.

En su texto, Marmontel los hace poseedores de la verdad, la moral, el arrojo y la lucha por el amor ante las dificultades y acciones de los conquistadores españoles.

\section{Historia de la Conquista del Perú}

La primera edición castellana de 1847 tenía tan solo una única ilustración en la que se representa a Francisco Pizarro con armadura en su cuerpo y un morrión con plumas en la cabeza. Seis años después, en la tercera edición de 1853, publicada en Madrid, incorporaron 50 grabados. Todos ellos buscan retratar una civilización diferente a la occidental y con importantes realizaciones culturales.

Las imágenes del libro de Prescott perduraron por décadas, durante las cuales fueron tomadas como históricamente válidas. Incluso las podemos encontrar en el capítulo correspondiente a la síntesis histórica, preparada por Horacio Urteaga, para el libro conmemorativo El Perú en el primer centenario de su Independencia de 1922.

Aunque menos idealizadas, las imágenes de este libro representan también un pasado imaginado en la mente

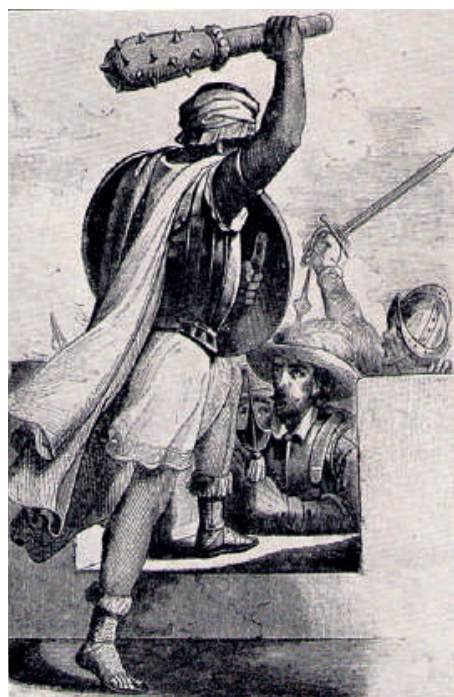

Fig.6. El texto original menciona: "Heroica defensa del Inca". Una de las imágenes más conocida corresponde a la mítica figura de Cahuide defendiendo una supuesta fortaleza almenada de Sacsayhuamán. El personaje incaico porta una larga capa de claro corte occidental. No tiene rostro, en contraposición con los españoles, y su fortaleza descomunal pareciera justificar una lucha en igualdad de condiciones. 
del ilustrador con no pocos yerros históricos. Sin embargo, como bien señala Alicia Mayer, docente de la UNAM, refiriéndose al libro Historia de la Conquista de México, del mismo autor y predecesor por cuatro años del texto referido a la conquista del Perú:

Este libro, como toda obra histórica, refleja juicios personales que son producto de una particular visión del mundo que, a su vez, se origina en una época determinada, y que ahora pueden resultarnos anacrónicos o falsos.

Asimismo observamos una incapacidad de su parte para valorar el mundo indígena a la par del europeo. Por momentos parece difícil distinguir las fronteras entre la historia y la novela².

Estos dos libros muestran finalmente, una visión idílica de nuestro pasado prehispánico que enalteció antes que depreció a nuestros antepasados. En ambos textos se nos considera seres humanos, con una cultura diferente y curiosa para el europeo, pero no por ello plenos de realizaciones y aportes.

AMÉRICA, Historia de su descubrimiento desde los tiempos primitivos hasta los más modernos

Ya menos fantástica, correctamente ilustrada, e históricamente pertinente, fue una publicación de conmemoración de amplia difusión en América Latina y España publicada en Barcelona en 1892, a propósito del IV centenario del descubrimiento de América.

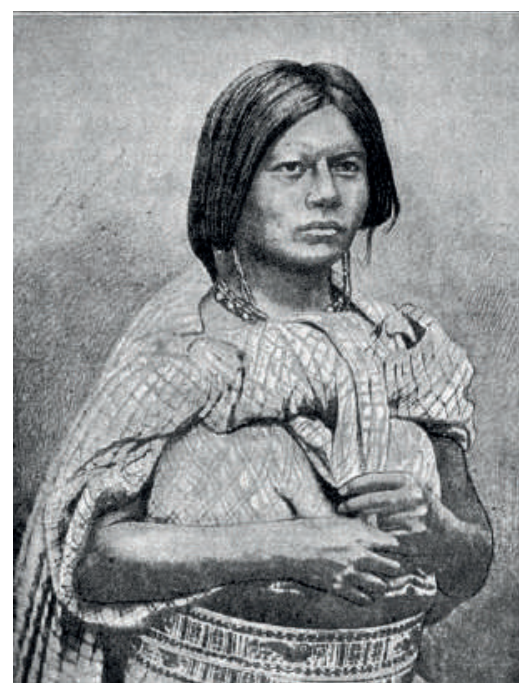

Fig.7. Cronau también se preocuparía en mostrar los diversos tipos de nativos de América con su respectiva vestimenta. En este caso el de "una india del Perú".

Para esa ocasión, el historiador y dibujante alemán Rodolfo Cronau, dirigió la importante colección que narra la historia de los pueblos primitivos del norte, centro y sudamérica. Cronau fue un gran investigador y eximio dibujante y esta producción fue muy difundida en Latinoamérica; aún hoy es relativamente sencillo conseguir ejemplares en buen estado de conservación gracias a la calidad de la impresión de estos tres volúmenes.

Los tomos están profusamente ilustrados y muchos de los dibujos son de la propia autoría de Cronau, quien copió de los objetos existentes en los Museos Etnográfico y de Instrucción Pública de Berlín, Museo de Instrucción Pública de Leipzig, Museo Etnográfico de Estocolmo, así como de fotografías y grabados de variada procedencia y de distinta época.

Todos las imágenes incorporadas por Cronau acompañan textos que narran respetuosamente los hechos y las realizaciones de las primeras culturas de América. Muestra objetivamente sus herramientas, objetos y construcciones arquitectónicas, incluida la vestimenta y fisonomía de los nativos, siendo sus referencias y fuentes auténticas. No hay en sus palabras ni en sus retratos algo denigrante contra el indígena americano, y existe en general una valoración positiva de ellos.

De nuestra cultura inca se expresa de la siguiente manera:

Todos trabajaban para el bien general; estaba severamente prohibida la holganza y no había pobres ni pordioseros, pues la comunidad tenía que atender a 
todos los ancianos o imposibilitados para el trabajo. Cada cual daba y recibía. Era, como dice muy acertadamente Ratzel, un estado socialista en el que muchísimas ocasiones tenía realización práctica cuanto han imaginado en Europa los más soñados utopistas respecto de la vida en familia de todo un pueblo (Cronau, 1892: 297- 298).

\section{Los primeros textos de Historia del Perú, apoyados en imágenes}

El libro fundacional que combinaba lo textual con lo visual con fines de enseñanza primaria, se editó en 1899 cuando Carlos Wiesse Portocarrero ${ }^{3}$ publicó su Resumen de la Historia del Perú, dirigido a la instrucción en colegios, siendo uno de los primeros elaborado por un peruano ${ }^{4}$.

En el texto de pequeño formato $(17 \times 11 \mathrm{~cm})$ y 306 páginas, se incorporan grabados dibujos y hasta fotograbados, novísima técnica gráfica que en el Perú tuvo sus inicios en 1898 con la incorporación de la foto del Sr. Luis Carranza, en el diario El Comercio, del cual fue su director en esos años.

Esta publicación tuvo innumerables reediciones y no es exagerado decir que toda la juventud peruana instruida en las tres primeras décadas del siglo XX conoció la Historia del Perú a través de los textos de Carlos Wiesse, y que las imágenes de sus libros pasaron a formar parte de la memoria historiográfica del país.

Por primera vez se difundieron en un texto escolar las realizaciones arquitectónicas de nuestros antepasados tal cual se encontraban en esos años, es decir sin ningún trabajo de restauración; así también se mostraron algunos pocos ejemplos de nuestra cerámica prehispánica, és-

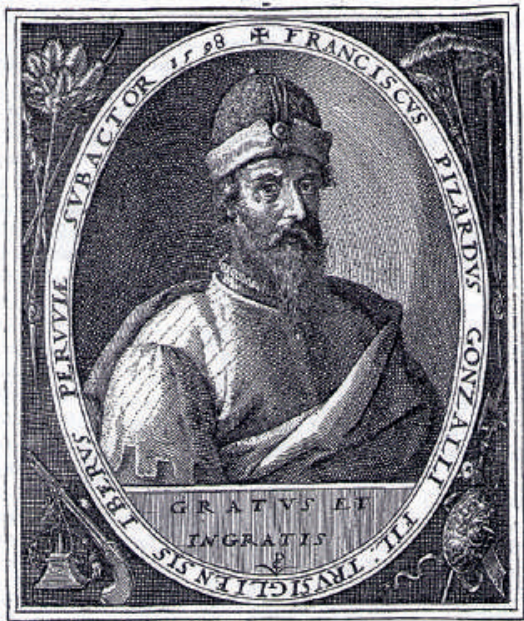

Fig.8. Grabado de Francisco Pizarro del siglo XVI incorporado en el tomo II de la colección América de Rodolfo Cronau. Años más tarde Carlos Wiesse incorporaría este grabado en sus textos elevando a Pizarro a categoría de "héroe". tos últimos tomados del libro de Cronau, aunque sin mencionar la fuente. Sin embargo, en este Resumen la gran mayoría de las imágenes y textos, correspondían al Virreynato y la República. El llamado Perú Antiguo y la historia del Imperio de los Incas, es decir casi cinco mil años de historia, quedaban reducidas a tan sólo seis páginas de las más de trescientas que tiene el texto.

Las láminas del texto de Carlos Wiesse también mostraban la segregación del indígena y de las otras razas no blancas en nuestro territorio, reducidos todos a una suerte de curiosidad, pero nunca considerados como parte integrante de la nación peruana. En una de las láminas (fig.9) indígenas descalzos "posan” para el retrato del dibujante quien no tiene cuidado de retocarlos ni civilizarlos, los muestra en los andrajos que revelan su miseria. Tres de los miembros de esta familia cargan tinajas que revelan su trabajo de aguadores. Ninguno sonríe, más bien parecieran estar a la espera de alguna dádiva. El rostro de la mujer es el más expresivo y lastimero.

3 Carlos Wiesse Portacarrero nació en Tacna en 1859 y murió en Lima en 1945.

4 Anteriormente, en 1868, Mariano Felipe Paz Soldán había publicado el primer tomo de su Historia del Perú Independiente, pero éste sólo trataba la historia patria desde la emancipación, es decir se narraban tan solo cinco décadas, y no contenían ningún dibujo o grabado. Sin ilustraciones también fue el caso del texto para escolares de Enrique Benites, Curso de Historia del Perú, de 1873, así como las Lecciones de Historia del Perú, que Elvira García y García publicó en 1894. 
Otra lámina (fig.10) muestra a cuatro "Indios salvajes" de Tarma con sus utensilios de caza. Su vestimenta es típica de la selva y los collares de dos de ellos están hechos con colmillos de alguna fiera del lugar. Para Wiesse, éstos correspondían a un tipo de "indio no domado" del cual aún había muchos en América y que "se conservaron y se conservan incólumes de todo contacto con las nuevas razas" (Wiesse 1906: 138).

En otra página (fig.11) vemos el retrato de un joven indigente con "tipo de zambo" y expresión infantil, ésta se incluye en el capítulo XXIX, llamado El Perú Colonial. En el mismo capítulo se dice de esta raza que:

es resistente cual ningún otro ser humano para el sol y los calores, las fiebres, los mosquitos y todas las plagas e incomodidades que matan al blanco y al indio en las hoyas de los grandes ríos sudamericanos, bravías y montaraces, que los debilitan en los vales de la costa peruana, en las otras costas ardientes del continente y en toda labor enervante y agotadora (Wiesse, 1906:138-139).

Las escenas parecieran pensadas para retratar a nuestros indígenas y etnias de un modo testimonial, pero menoscabados, antes que dignos. A diferencia de las imágenes de Marmontel, Prescott o Cronau, lo que se muestra aquí es una desvalorización y la condición de atraso y miseria; las razones de ello no eran comentadas en los textos, más si mostrada en las imágenes.

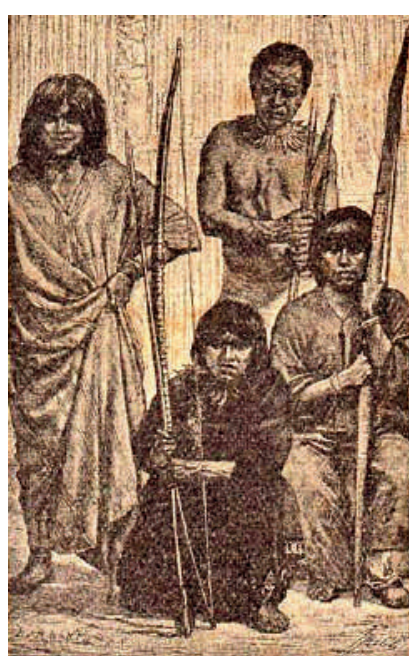

Fig.10. Otra de las imágenes de etnias peruanas, incluida en los textos escolares de Wiesse.

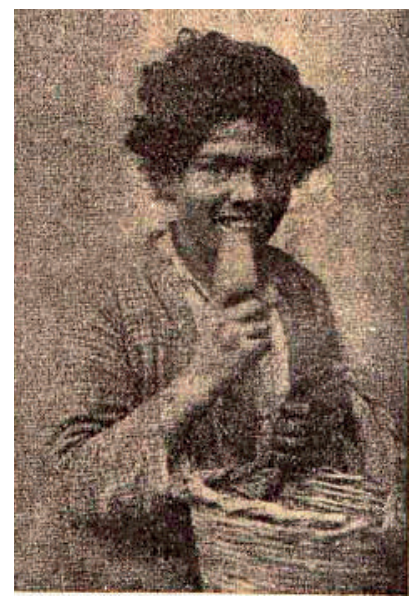

Fig.11. Fotografía atribuida al estudio Courret Hermanos que muestra a un "tipo de zambo".

También incorporada en los textos de Carlos Wiesse.

Seguido de estos retratos se mostraban también a nuestros próceres, mandatarios y militares criollos siempre impecablemente uniformados, exhibiendo sus condecoraciones, y posando orgullosos para el fotógrafo o el pincel del artista.

Cabe aquí una reflexión ¿qué pensamientos fluirían en los niños peruanos ante imágenes tan dispares de sus connacionales en un mismo documento? Retratos que, por un lado, mostraban a las razas autóctonas en un estado de casi indigencia, su nula referencia ni mención en la vida ciudadana, y por el otro la meticulosidad, el detalle y cuidadosa postura fotográfica de los caudillos y dirigentes criollos del siglo XIX, así como de sus hechos y obras realizadas. $\mathrm{Si}$, como hemos visto, ya existían textos e imágenes con una mejor disposición hacia el indígena ¿por qué Wiesse no las utilizó? 

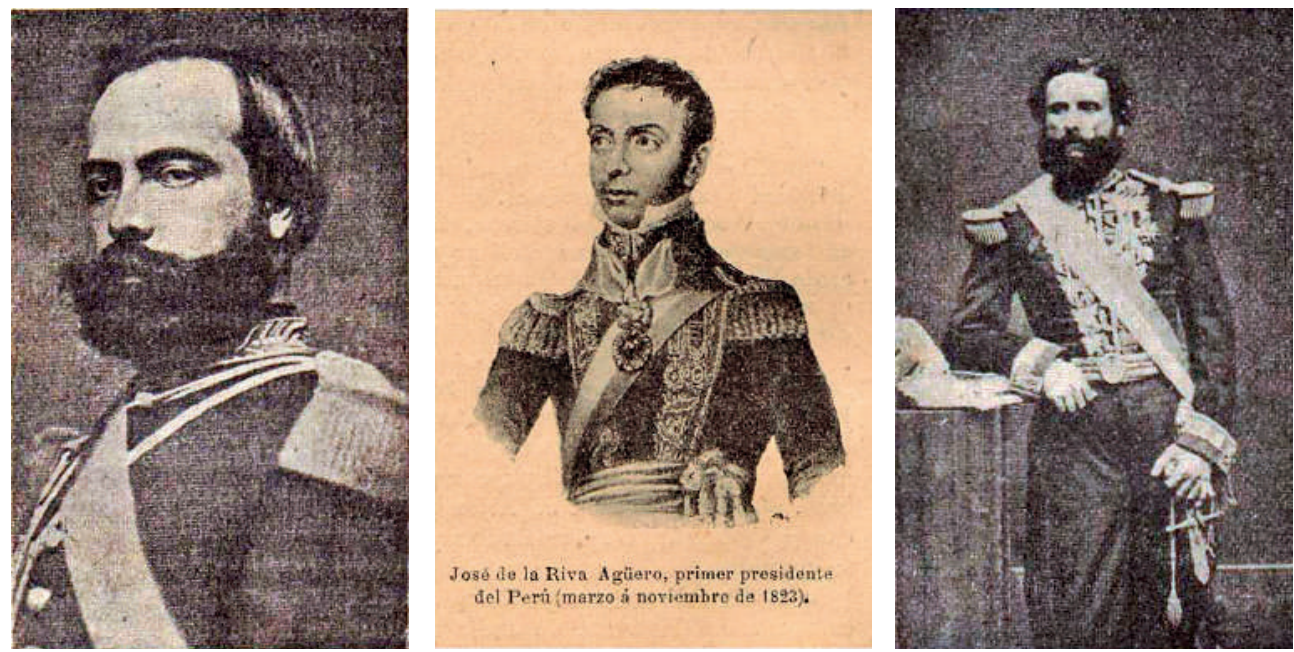

Fig. 12, 13 y 14. Tres gobernantes peruanos ataviados con sus galas militares en el texto de Wiesse.

La respuesta a esta pregunta, que finalmente se refiere a la propia ideología del autor, la encontramos en su mismo texto. Efectivamente en las primeras páginas de su libro Resumen de Historia del Perú, habla de nuestras razas andinas indicando:

El carácter de los aborígenes quichuas-aimaraes, así como el de todos los americanos, se distingue por la lentitud de su excitabilidad y el poder de resistencia pasiva, unidos a un exterior tranquilo, una fuerza de sufrimiento y una prudencia general en los actos de la vida, llevados a su más alto grado. Esta pintura se completa observando el aire de tristeza reflexiva de su fisonomía, y aún la gran reserva y astuta desconfianza que gastan en su trato con los blancos (Wiesse, 1906:4).

Sufrimiento, tristeza, reserva y astuta desconfianza, es lo que justamente transparentan los personajes de las láminas que incorporó, por lo que se deduce que Wiesse necesitaba imágenes que apoyaran su discurso.

Del mismo modo, cuando se refiere a Manco Cápac primero cita a Garcilaso de la Vega, cuando éste pone en duda la leyenda acerca del origen divino, pero luego escribe:

Otros escritores españoles refieren diversas leyendas, que no suministran datos para afirmarse la existencia real de Manco Cápac.

En todo caso, si este personaje existió, fue un reyezuelo jefe de bandas invasoras, que vivió en constantes reencuentros y combates por la posesión de los territorios de Pacaritambo y el Cuzco (Wiesse, 1906:19).

Esta despectiva descripción de Manco Cápac aún continuará citándola hasta 1935, como se puede corroborar en la séptima edición del texto Historia del Perú Prehispánico de aquel año, dedicado exclusivamente a esta etapa inicial de nuestra historia.

Y acerca de las costumbres domésticas de nuestros antepasados dice:

Higiene.- Los indios, como hasta ahora, carecían de toda idea de higiene. Los Incas tenían baños, pero el común de los habitantes ni siquiera se lavaba. Las pestes encontraban por eso terreno preparado para sus estragos (Wiesse, 1906:19). 
Aquí citamos a Portocarrero y Oliart $^{5}$ quienes, desde su óptica sociológica coinciden con nuestras deducciones que parten de la iconografía:

Es como si Wiesse se sintiera aliviado de encontrar diferencias sociales y satisfechas de expresarlas, en tanto ello permitía considerar normal la situación del Perú en el momento en que él escribe, situación marcada por la desigualdad y la existencia de un abismo cultural entre grupos sociales (Portocarrero y Oliart, 1989:52).

\section{María Rosay, una historia olvidada}

Es recién en la segunda década del siglo XX que una educadora francesa llamada María Rosay ${ }^{6}$ brindó una perspectiva más justa de nuestra historia en sus textos escolares. De formación educadora, con estos volúmenes ella deseaba corresponder de algún modo al país que la había acogido.

Su libro Mi Primera Historia del Perú, cuya primera edición debe haber ocurrido hacia 1920, incorpora desde su carátula y contra carátula, elementos traídos de la iconografía del Perú Antiguo creando una ornamental y atractiva portada.

El texto estaba profusamente ilustrado y sus imágenes buscaban mostrar un pasado preincaico e incaico pleno de magníficas realizaciones y avances en las técnicas de producción agrícola, textilería, geografía y orfebrería.

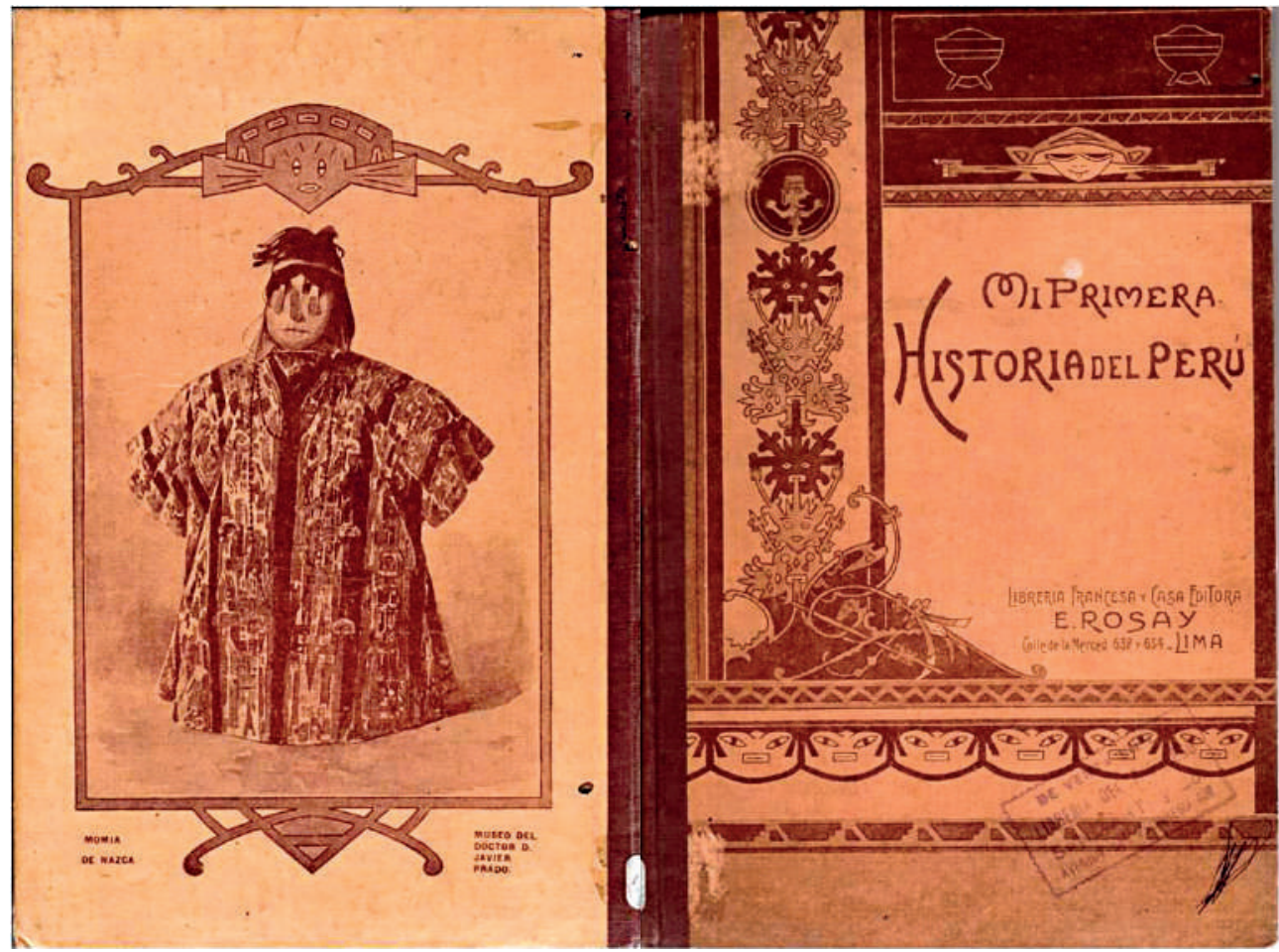

Fig.15A y 15B. Carátula y contra carátula del libro Mi primera historia del Perú, de María Rosay. Este diseño, atribuible a Elena Izcue, perduró al menos hasta la 6ta edición de 1926.

5 El trabajo sociológico de ambos investigadores incluyó la revisión de textos de Historia, la visita a 59 colegios, entrevistar a 68 profesores y encuestar a 1,690 estudiantes.

6 María Rosay pertenecía a la familia dueña de la célebre Librería Francesa y Casa Editora E. Rosay, la cual publicó muchos textos desde fines del siglo XIX, entre ellos los libros de Carlos Wiesse. 


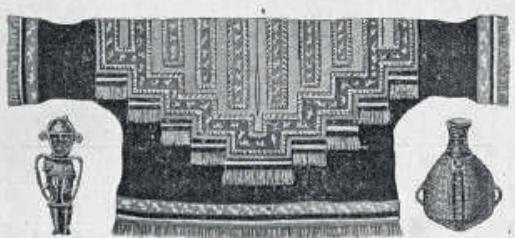

ÉPOCA ${ }^{\prime}$ PREINCAICA'

Tiempos antiguos (a. do $\mathrm{J}, \mathrm{C}$

Los primitivos pobladores del Perú, nuestra patria, vivian en estado salvaje. Eron cazadores o pescadores.

Cultivaron luego ha papa y otros frutos comestibles $y$ domesticaron la llama.

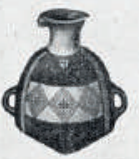

Vivian en chozas de carrizo y barro, en la costa, $y$ de piedras en la sierru. El traje que llevaba los habitantes tampoco era com el que usumos: los hombres se vestian con uncu (camisón), huaru (calzones); las mujeres con yocalla (manto), liticla (rebowo); Ilevaban (manto, licla (rebozo); llevaban einturones) y llautu (bandas frontales) y una especie de gorros. Con un aparato llamado piruru, hilabon unos tejidos finisimos y de delicados colores. Fabricaban vasijas de barro adornadas con figuras de aves. pescados, etc. Trabajaban el cobre, el oro y la plata para hacer adornos, collares, brazaletes $\mathrm{y}$, tumbién idolos. Bn tumbas antiquisimas se han

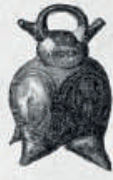

encontrado vasos y adornos de verdadero valor artistico con piedras preciosas incrustadas.

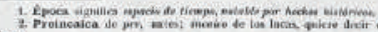

Epocs frexcatcs

Era general el eulto a cierios onimales, entre ellos el tigre, la serpiénte $y$ la lechuza.

En la costa los antigues peruanos adoraban al díos Con y a Pachacamac (creador del Universo). En la sierra, ndoraban al poderoso Viracocha dilos del diluvio) a quicn elevaron un templo en Cocha.

La cultura de estos primitivos se desarrollo en regiones que tuvieron como centros principales : Chavin, Tiahuanaco, Chicama Nasca

Se admitan todayia lus ruinas de los templos bagrados construidos pot nuestros antepasados : el Templo de Chavin, el de Pacha camac en el valle de Lurin; el templo de Viracocha, levantado en Cacha; el palacio de
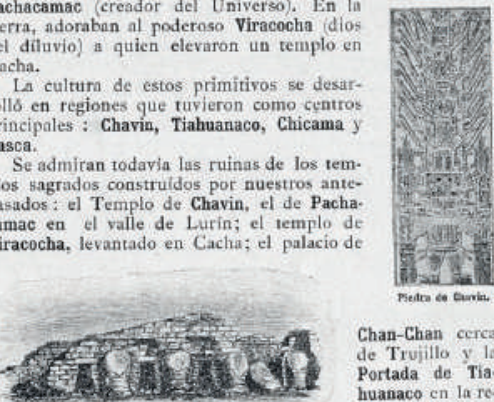

Chan-Chan cerca de Trupillo y la Portada de Tia. huanaco en la re. gión del Titicaci.

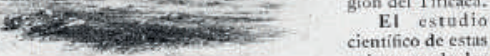

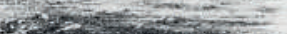

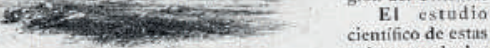
ruinas y de los. objetosallienconsutar de rachasamac. objetosalliencontrados, prucban
antes del grandioso

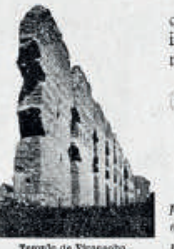
que muchos siplos antes del grandioso imperio incaico, el Perú fué poblado por razas de adelantada cultura.

Esta época se llama Epoca preincaica es decir, antes de los Ineas).

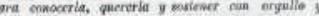

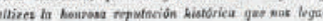
ron nuestros enticpasados.

Fig.16. Páginas 8 y 9 del libro de Rosay.

Es sintomático que Rosay no utilizara el término "indígena" en su libro, sino el de "primitivos pobladores" al referirse a la época preincaica, y "antiguos peruanos" a los que corresponden a la época incaica.

Las hojas de su texto muestran la marcada intención de apoyarse en las imágenes, que ocupan casi un 50\% de las hojas, como las que se muestran en las figs. 16 y 17. En éstas se

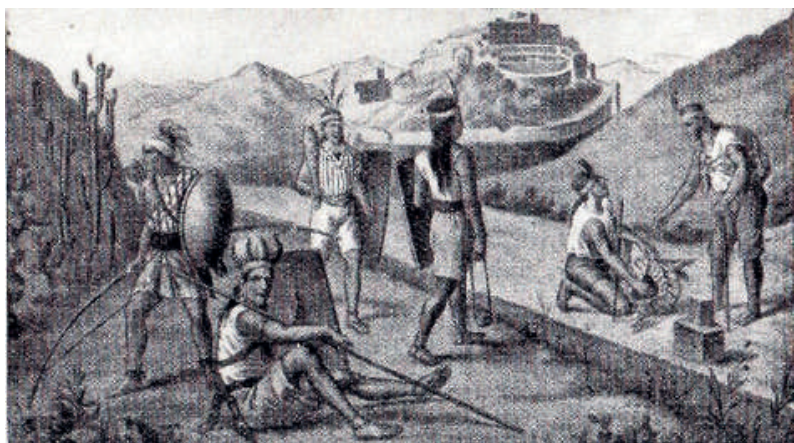

Fig.17. Construcción de caminos incas. destacan importantes realizaciones culturales del Perú prehispánico en textilería, cerámica, arquitectura, trabajo en piedra, así como en la construcción de caminos.

La fructífera labor de Rosay comprendió también la edición de cuadros murales de la Historia del Perú para ser colgados en las paredes de las aulas escolares; en total fueron 19 litografías impresas en cartulina de 0.67 por $0.55 \mathrm{mts}$. con dibujos que mostraban el desarrollo histórico del país, e impresas por la casa Editora E. Rosay de propiedad de su familia.

\section{Conclusiones}

A principios del siglo XX las imágenes de nuestra historia comienzan a ser construidas y difundidas. Sin embargo los primeros textos escolares siguieron adoleciendo de una visión 
europeizante del mundo y no reconocieron ni valoraron a quienes eran la mayoría de habitantes de su país ni los importantes logros que habían obtenido en diferentes campos de la cultura.

El Resumen de Historia del Perú de Carlos Wiesse desde su primera edición y las sucesivas, es en esencia un Resumen de la Historia del Español en nuestras tierras y de los criollos que, luego de la Independencia, se sucedieron en el poder de un gobierno para el cual los indígenas no tenían ninguna participación. Lo mismo ocurrió con otros textos de este autor, que repitieron el mismo esquema segregacionista y excluyente por lo menos hasta 1937,

Los primeros textos escolares realizados en el Perú de fines del siglo XIX y principios del XX, producidos por Carlos Wiesse Portocarrero, no tuvieron un fin integrador, por el contrario se desvalorizó al peruano de ascendencia indígena tildándolo de conformista, apático y falto de higiene, y atribuyendo a una condición biológica su aparente pasividad.

Las imágenes incorporadas, que de seguro fueron más rápidamente asimilables que los textos, correspondieron a la visión sectaria y excluyente del propio autor; en ese sentido dichas láminas no fueron ingenuamente escogidas. Existiendo otras que mostraban una visión favorable a este sector mayoritario de la población, Wiesse prefirió obviarlas al parecer por el peligro de acercarlos a su propio concepto de civilización.

Las láminas seleccionadas llevaban y trasmitían una carga ideológica dirigida a exaltar al criollo y a menospreciar al indígena. Sólo hubo identificación por algunos logros de nuestros antepasados prehispánicos pero con reservas; se prefirió mostrar los hechos pero no a quienes lo concretaron.

De este modo, la visión del niño instruido durante más de tres décadas se formó con un concepto negativo respecto a sus connacionales. Aprendió a reconocer y valorar al Perú antiguo, pero no podía comprender que los descendientes de aquellos primitivos peruanos fueran sus pares. Dentro de este esquema desvalorativo y sistemáticamente aprendido y repetido durante años, era fácil prever que una gran parte de nuestra población no tuviera ninguna participación en la organización del estado, y que viera a éste con razonable desconfianza.

Ante su entorno social, Wiesse legitimó la desigualdad y la sustentó con falsas y maniqueas afirmaciones acerca de la condición sub desarrollada, per se, de las mayorías indígenas. Es entendible entonces que la situación de analfabetismo, atraso y miseria, perdurara con muy pocos avances durante décadas; los gobernantes instruidos desde su niñez, con estas imágenes y textos primigenios fueron (de)formados conscientemente.

Diferente fue el caso de María Rosay, hasta hoy un personaje desconocido en la historia de la educación peruana y que nuestra investigación pretende rescatar. Su influencia es de seguro enorme y valiosa a pesar que nadie aún lo ha reconocido. Sus imágenes y sus escritos reflejan el aprecio que tuvo por el Perú, y de seguro ella colaboró positivamente en la creación de una conciencia nacional que partía de reconocer y de mirar con aprecio su pasado milenario. Mostrando a los antiguos pobladores construyendo su entorno, hacía notar a los niños que éstos fueron quienes forjaron su pasado y a quienes debían reconocer como sus primeros y válidos antepasados.

Las imágenes no son inocentes y trasmiten ideología. Calan en el inconsciente, positiva o negativamente, y pueden crear sentimientos ya sea de orgullo, aprobación, o rechazo.

Es probable que dentro de algunos años la imagen digital, animada y posiblemente tridimensional, ocupe lugar preferencial en la educación. Su captura y divulgación tendrán nuevos soportes, maneras rápidas de encontrarlas y retrasmitirlas variarán la forma tradicional de la enseñanza que, con pocos cambios, permaneció inalterable por siglos a través 
de los libros. Sin embargo, seguirán existiendo elementos visuales con su inherente carga semiótica, por lo que no debemos olvidar que, cualquiera sea el vehículo en el que viaje, la imagen trasmitirá ideología, por tanto su uso deberá ser cuidadosamente considerado.

\section{Referencias}

Benites, E. 1873. Curso de Historia del Perú para el colegio Peruano. Lima: Imprenta del Estado.

Cronau, R. 1892. América, Historia de su descubrimiento desde los tiempos primitivos hasta los más modernos. Barcelona: Montaner y Simón Editores.

García y García, E. 1894. Lecciones de Historia del Perú. Lima: Imprenta El Nacional.

Marmontel, J. F. 1991. Les Incas, ou la destruction de L'Empier du Pèrou. Lima: Instituto Francés de Estudios Andinos.

Mayer, A. 2001. William H. Prescott. En El surgimiento de la historiografía nacional, Vol III. México DF: Universidad Autónoma de México.

Pestalozzi, J.H. 1888. De cómo Gertrudis educa a sus hijos. Versión castellana de José Tadeo Sepúlveda. Dresden: A. M Rebolledo.

Portocarrero, G. y P. Oliart. 1989. El Perú desde la Escuela Lima. Pontificia Universidad Católica del Perú.
Prescott, W. 1853. Historia de la Conquista del Perú. Madrid: Imprenta y Librería de Gaspar y Roig Editores.

Rosay, M. 1926. Mi Primera Historia del Perú. Lima: Casa Editorial E. Rosay. Cuarta edición.

Sud-Americaine Monte Domecq. 1922. El Perú en el primer centenario de la República, Berlín: Gebr, Feyl, Friedricchstr.

Squier, G. 1877. Peru: Incidents of travel and exploration in the land of the Incas. New York: Harper \& Brothers Publishers.

Wiesse, C. 1906. Resumen de Historia del Perú. Lima: Librería e Imprenta E. Rosay.

Wiesse, C. 1928. Historia del Perú y de la Civilización Peruana. Lima: Librería e Imprenta E. Rosay.

Wiesse, C. 2005. Resumen de Historia del Perú (hasta 1908).Lima: Instituto Nacional de Cultura, Lima. 